\title{
Impact of global warming on beef cattle production cost in Brazil
}

Irenilza de Alencar Nääs ${ }^{1 *}$; Carlos Eduardo Bites Romanini²; Douglas D’Alessandro Salgado ${ }^{2}$; Karla Andrea Oliveira Lima²; Marcos Martinez do Vale ${ }^{2}$; Marcelo Ricardo Labigalini'; Silvia Regina Lucas de Souza ${ }^{3}$; Adriana Gomes Menezes²; Daniella Jorge de Moura $^{1}$

${ }^{1}$ UNICAMP/FEAGRI - Lab. de Conforto Térmico, C.P. 6011 - 13083-970 - Campinas, SP - Brasil.

${ }_{3}^{2} U N I C A M P / F E A G R I$ - Programa de Pós Graduação em Engenharia Agrícola.

${ }^{3}$ UNICAMP/CT, Cidade Universitária Prof. Zeferino Vaz, C.P. 6131 - 13083-866 - Campinas, SP - Brasil.

*Corresponding author <irenilza@agr.unicamp.br>

ABSTRACT: Global warming is affecting agribusiness in its economic aspects. Therefore, the prediction of the evolution of Brazilian beef cattle production cost was made using the IPCC forecast scenario for global warming. The methodology consisted of two steps: (i) the development of a fuzzy model that estimated the grazing land capacity $(\mathrm{RP})$ decrease risk as a function of the changes in the average total rain index, air temperature and increase in extension of the dry season; and (ii) the design of an algorithm for predicting the decrease in production as function of the RPfuzzy model, that results in the impact in beef cattle productivity, and consequent increase in production costs. Historical environmental data from important producing counties in the Cerrado were organized and a set of fuzzy Gaussian functions were developed, and three possible settings (optimistic, medium and pessimistic) were considered. The decrease in beef cattle productivity was estimated using the losses in production due to the increase in air temperature and vulnerability of pasture capacity. The boundary settings for the total increase of production cost scenario used the number of animals per area of grazing land, the adoption of grain supplement and its future scenario; and the result output function pointed to a threshold within a variation from an increase in production cost of $80 \%$ (optimistic) to $160 \%$ (pessimistic). Under the optimistic scenario the total cost of Brazilian beef cattle production in the Cerrado became near to US\$2.88 $\mathrm{kg}^{-1}$, while in the pessimistic scenario this cost reached US\$ $4.16 \mathrm{~kg}^{-1}$, challenging the international competitiveness of this economic segment.

Key words: dry season, environmental temperature, fuzzy simulation, mathematical modeling

\section{Impacto do aquecimento global no custo de produção de carne bovina no Brasil}

\begin{abstract}
RESUMO: $\mathrm{O}$ aquecimento global afeta o agronegócio em seus aspectos econômicos. Foi feita previsão da evolução do custo de produção de carne bovina brasileira usando a predição de aquecimento global do IPCC. A metodologia consistiu de duas etapas: (i) o desenvolvimento de modelo fuzzy que estimou o risco de decréscimo da capacidade de pastagens (RP) em função das mudanças no índice pluviométrico total, na temperatura do ar e na extensão da estação de seca; e (ii) o desenvolvimento de um algoritmo para predição do decréscimo da produção em função de um modelo fuzzy de RP que resulte no impacto na produtividade bovina de corte e conseqüente aumento no custo de produção. Foram organizados os dados históricos de fatores ambientais dos municípios importante produção no Cerrado e um conjunto de funções Gaussianas fuzzy foi desenvolvido e três estimativas possíveis (otimista, média e negativa) foram consideradas. O decréscimo na produtividade do gado foi estimado usando as perdas de produção devido ao acréscimo da temperatura bem como da vulnerabilidade da capacidade de pastagem. O estabelecimento dos limites para o cenário do acréscimo do custo de produção usou o número de unidade animal por área de pastagem, a adoção de suplemento de grãos e o cenário de produção futura; e o resultado da função de saída apontou para uma variação do acréscimo do custo de produção de $80 \%$ (otimista) até $160 \%$ (pessimista). Sob o cenário otimista, o custo total da produção brasileira de carne bovina no Cerrado chega a US\$2,88 $\mathrm{kg}^{-1}$, enquanto no cenário pessimista este custo pode atingir US $\$ 4,16 \mathrm{~kg}^{-1}$, o que pode comprometer a competitividade internacional do setor.

Palavras-chave: estação seca, temperatura ambiente, simulação fuzzy, modelagem matemática
\end{abstract}

\section{Introduction}

Brazilian beef cattle herd has near 206 million heads (IBGE, 2006) with $97 \%$ reared on native and/or planted pastures and $75 \%$ on the Cerrado ${ }^{1}$ area. Global warming and sustainability issues can be considered at a large number of levels as well as related to several environmental conditions. According to the IPCC ${ }^{2}$ forecast, glo-

${ }^{1} \mathrm{~A}$ vast tropical savanna ecoregion of Brazil located mainly in the Center West of the country.

2Intergovernmental Panel on Climate Change is a scientific intergovernmental body set up by the World Meteorological Organization (WMO) and by the United Nations Environment Programme (UNEP). 
bal ambient temperature is likely to increase up to $5^{\circ} \mathrm{C}$ until the end of this century affecting in an overall way agricultural and animal production (Bates et al., 1996; Brklacich et al., 2000; Chiotti and Johnston, 1995; CIG, 1996; IPCC 2001, 2001a; IPCC, 2007; Specht and Specht, 1995) and this kind of global change leads to broad shifts in socio-economic systems (Hall et al., 1998; Harrington and Lu, 2002; Howden et al., 1999; McCown et al., 1981; Mott et al., 1985; Stafford Smith and Foran, 1992; Topp and Doyle, 1996;), as well as bio-physical changes (Foran and Stafford Smith, 1991; Graetz et al., 1988; Marcelino, 2007). Possible variation in agricultural yield facing global warming has been established (McKeon et al, 1998; Siqueira et al., 1994; Smith and McKeon, 1998; Stafford Streck and Alberto, 2006) and trends of modification in rainfall indexes leading to droughts not only in the Cerrado area, but also expanding towards the Amazon basin, have been reported (Marcelino et al., 2006; Marcelino, 2007; Sombroek, 2001).

Models for assessment of grazing land use and its change through time, as well as beef cattle growth on pasture are available in the current literature (Clewett et al., 1991; Clipperton and Bean, 2007; Feer et al., 1997; Hendricksen et al., 1982; McKeon et al., 1980; McCown, 1981; Stafford Smith and Foran, 1992; White, 1978; Wicksteed, 1980). Fuzzy inference systems can be used for estimating scenarios of high degree of uncertainty, and that are based on empirical analysis of which the main principle is the "Postulate of Possibilities" (Amendola et al., 2004; Bellman and Zadeth, 1970;
Oliveira et al., 2005). As Brazilian beef cattle production is strongly dependent on planted pasture and highly influenced by international competitors (including world grain production), the global warming impact is likely to influence beef prices, as in other countries that use grazing land for pasture (Herne, 1998; White 1972;).the objective of this study was to estimate the beef production cost in Brazil under the IPCC forecast of climate change, using fuzzy logic.

\section{Material and Methods}

A database was built up using the values of historical data (last sixty years) of average monthly air temperature $\left(T,{ }^{\circ} \mathrm{C}\right)$ and monthly rainfall index $(\mathrm{RF}, \mathrm{mm})$ considering only the months that presented an amount of total rainfall lower than $100 \mathrm{~mm}$, typical for the Cerrado dry season. As $75 \%$ of Brazilian beef cattle herd is located in the Cerrado region (Figure 1) the data used stem from twenty meteorological stations located in counties which are referred as large producers in that region (IBGE, 2006; Rangel et al., 2007).

The methodology consisted of two steps: (i) the development of a fuzzy model that estimated the pattern risk of decreasing the grazing land capacity (quality and quantity) as function of the combination of the total rainfall index $(\mathrm{mm})$, average data of monthly air temperature $\left({ }^{\circ} \mathrm{C}\right)$, and increase in extension of the dry season (days); and (ii) the design of an algorithm for predicting the decrease in production as function of the risk of pas-

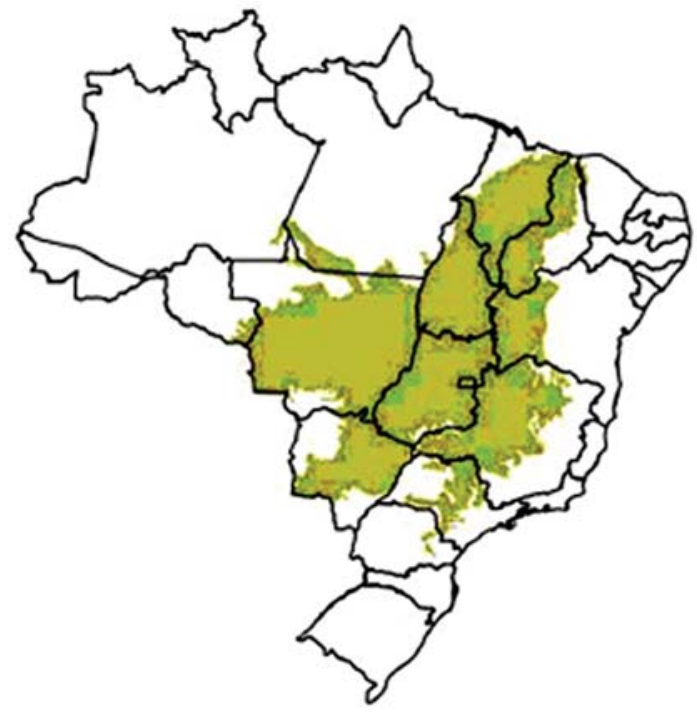

a

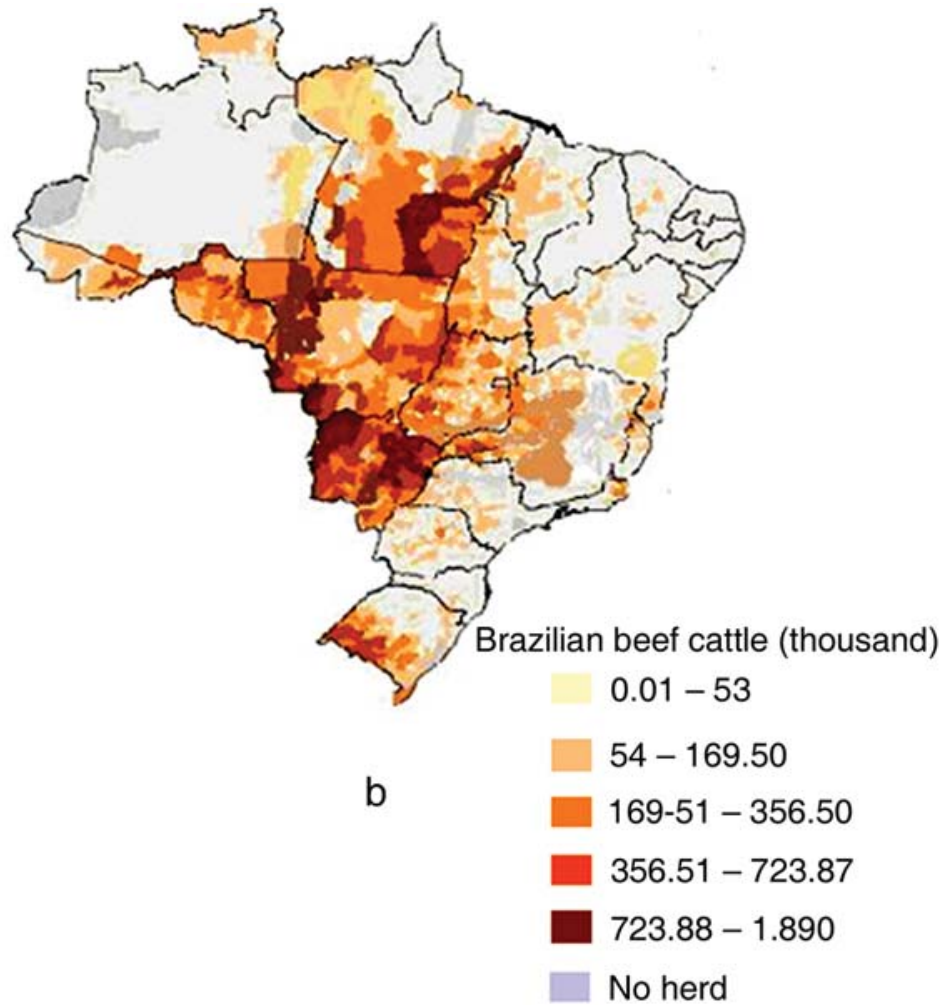

No herd

Figure 1 - Scheme comparing the Brazilian biome Cerrado (a) and the distribution of beef cattle herd (b). (Adapted from Diniz, 2006 and IBGE, 2006). 
ture $(\mathrm{RP})$ that led to the impact in beef cattle productivity, and consequent increase in production costs to mitigate the problem.

Development of the fuzzy inference system for describing the risk of drought in pastures

A model was developed using fuzzy logic in order to estimate the risk pattern of decreasing the pasture capacity (function named "risk of pasture"; RP) as a function of the 60 years average data on: monthly rainfall index $(R F)$, monthly air temperature $(T)$, and extension (in days) of the dry season (DS). The base of rules used for stating RP came from data found in current literature (Ruiz et al., 1984; Zimmer and Euclides Filho, 1997).

Pertinence functions (in X, Eq. 1) were described relating the elements of the domain (average monthly air temperature, monthly rainfall index, dry season in days, and risk of pasture) in an unit interval $[0,1]$, as follows:

$\mu_{A}: X \rightarrow[0,1]$

where the value of $\mu_{A}(x) \in[0,1]$ indicates the degree the element $\times($ of $X)$ is in the A cluster with $\mu_{A}(x)=0$ and $\mu_{A}(x)=1$ (non-pertinence and pertinence of $\mathrm{A}$ ).

Some scenarios of rainfall deficit (rainfall d" $100 \mathrm{~mm}$ ) and changes in the expansion of the dry season by 30 days ( 15 days prior to the start and 15 days after the season) were considered and used as input variables. Historical meteorological data from twenty counties where the majority of the herd is located, with an overlap location of the biome Cerrado and the Center West, North and Southern geographic regions of Brazil (Figure 1), were selected and organized. The gradual change forecasted by the IPCC scenarios was used to build up the base of rules (IPCC, 2001; IPCC, 2007). The follow up diagram for applying the fuzzy inference functions is shown in Figure 2.

The start up scenario was drawn using actual data of the selected counties, where in the dry season the average monthly air temperature was $21.7^{\circ} \mathrm{C}$, the amount of average monthly rain index was $45.5 \mathrm{~mm}$, and the average length of dry season was 150 days. Using this as the normal scenario, the extreme boundaries using the most favorable and unfavorable conditions in the dry sea- son were drawn. The most critical scenario was considered using the following concomitant conditions: increase of $5^{\circ} \mathrm{C}$ in the average air temperature, decrease in $60 \%$ of the total amount of rain, and increase in the dry season of 30 days ( 15 days prior to the start and 15 days after the season).

To determine the drought response on extensive grazing herds due to spatial and temporal variation in climate and length of the dry season, another base of rules was adopted. The rules were set for describing the grazing system as a result of a combination of air temperature and amount of rainfall that determines both carrying capacity (animal units per ha) and production per head (death, births and mortalities), as suggested in Campbell et al. (1996) and Campbell et al. (1997).

The vulnerability of pasture capacity (RP, \%) was also expressed as a fuzzy function (Eq. 2 and Eq. 3).

$\mathrm{RP}=f\left\{\left(f_{1}\right), \mathrm{DS}\right\}$

where $f_{1=} f(\delta \mathrm{T}, \mathrm{RF})$

Data from $\mathrm{T}$ and RF were organized and a set of fuzzy Gaussian pertinence functions were developed. From the Gaussian functions the linguistic fuzzy rules were organized (Tables 1 and 2) and a model was built. For building up the fuzzy rules changes that may occur in the average values of the variables were taken into account, such as 1 to $5^{\circ} \mathrm{C}$ increase in the air temperature (IPCC, 2001a,b; IPCC, 2007), and variation on the rainfall index. It was also assumed that all values had normal distribution. The increment of $1^{\circ} \mathrm{C}$ for the air temperature, and three times the values of the standard error (SE) found in the average distribution were then chosen to move the average value of rainfall index either up or down. Variations in the extension of the dry season in days, with an increase or decrease of 30 days (15 days prior to the start and 15 days after the season) were used as input variable, in order to design the set of rules for predicting RP function. The rain index deviation was estimated adopting a function of the standard error (SE) derived from the values computed from the historical data, and dispersed in equal proportions from the average (Table 1). The use of three nominal standard

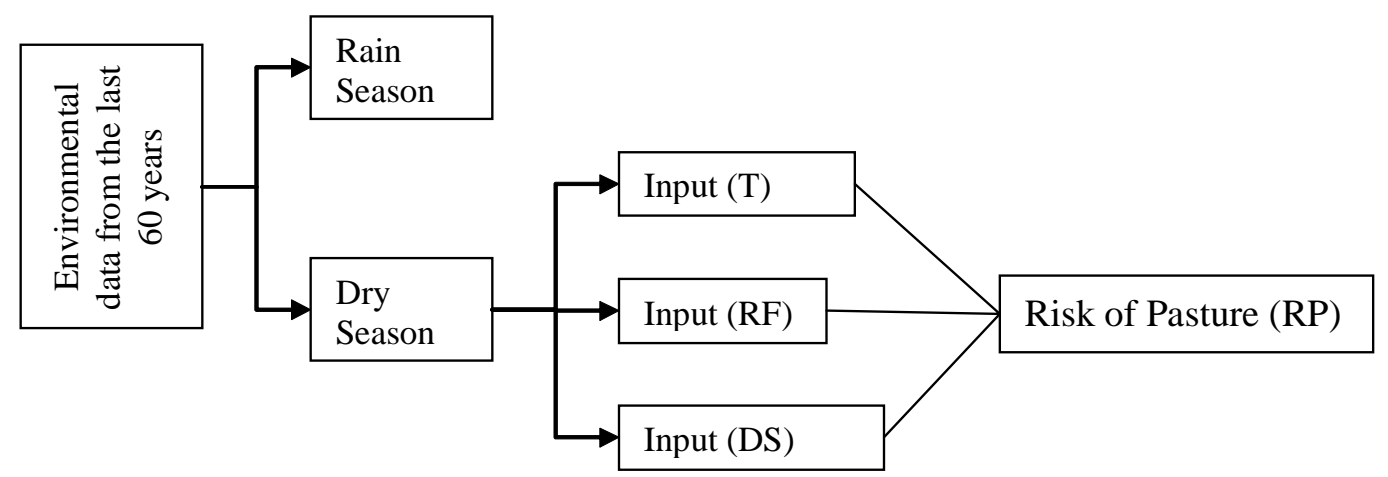

Figure 2 - Diagram of the fuzzy model construction from the base of rules, for developing the related inference functions. 
Table 1 - Base of rules for setting the fuzzy function $\left(f_{1}\right)$ in order to determine thevulnerability/risk of pasture capacity (RP).

\begin{tabular}{|c|c|c|c|c|c|c|c|}
\hline & \multicolumn{7}{|c|}{ Average air temperature $\left({ }^{\circ} \mathrm{C}\right)$} \\
\hline & & $\mathrm{T}$ & $\mathrm{T} 1$ & $\mathrm{~T} 2$ & T3 & $\mathrm{T} 4$ & $\mathrm{~T} 5$ \\
\hline \multirow{5}{*}{$\begin{array}{l}\text { Average } \\
\text { rainfall } \\
\text { Index } \\
(\mathrm{mm})\end{array}$} & Rain - 6SE & $\mathrm{LN}$ & $\mathrm{LN}$ & $\mathrm{LN}$ & $\mathrm{LN}$ & $\mathrm{LN}$ & $\mathrm{LN}$ \\
\hline & Rain - 3SE & $\mathrm{SN}$ & SN & $\mathrm{MN}$ & $\mathrm{MN}$ & $\mathrm{LN}$ & LN \\
\hline & Rain & zero & SN & $\mathrm{MN}$ & $\mathrm{MN}$ & $\mathrm{LN}$ & LN \\
\hline & Rain $+3 \mathrm{SE}$ & MP & MP & SP & SP & zero & zero \\
\hline & Rain +6SE & LP & LP & MP & MP & SP & SP \\
\hline
\end{tabular}

$\mathrm{T}=$ average ambient temperature; $\mathrm{T} 1=\mathrm{T}+1{ }^{\circ} \mathrm{C} ; \mathrm{T} 2=\mathrm{T}+2^{\circ} \mathrm{C} ; \mathrm{T} 3=\mathrm{T}+3^{\circ} \mathrm{C} ; \mathrm{T} 4=\mathrm{T}+4^{\circ} \mathrm{C} ; \mathrm{T} 5=\mathrm{T}+5^{\circ} \mathrm{C} . \mathrm{LN}=1 \mathrm{arge}$ negative; $\mathrm{SN}=$ small negative; $\mathrm{MN}=$ medium negative; $\mathrm{MP}=$ medium positive; $\mathrm{LP}=$ large positive; $\mathrm{SP}=$ small positive.

Table 2 - Base of rules for setting the fuzzy function to describe the vulnerability/risk of pasture capacity (RP) using distinct pertinence degrees.

\begin{tabular}{|c|c|c|c|c|c|c|c|c|}
\hline & \multicolumn{8}{|c|}{ Vulnerability of pasture capacity (\%) } \\
\hline & & LN & MN & SN & zero & SP & MP & LP \\
\hline \multirow{3}{*}{$\begin{array}{l}\text { Extent } \\
\text { of dry } \\
\text { season } \\
\text { (days) }\end{array}$} & Prolonged & $\operatorname{LN}(1.0)$ & LN (0.5) & MN (0.5) & SN (0.5) & $\mathrm{SP}(0.5)$ & LP $(0.5)$ & $\operatorname{LP}(1.0)$ \\
\hline & Normal & $\mathrm{LN}(0.5)$ & $\mathrm{MN}(1.0)$ & $\mathrm{SN}(1.0)$ & Zero $(1.0)$ & $\mathrm{SP}(1.0)$ & MP (1.0) & LP $(0.5)$ \\
\hline & Reduce & $\begin{array}{l}\mathrm{LN}(0.1) \\
\mathrm{MN}(0.9)\end{array}$ & $\begin{array}{l}\mathrm{NM}(0.1) \\
\mathrm{SN}(0.9)\end{array}$ & $\begin{array}{c}\text { SN }(0.5) \\
\text { Zero }(0.5)\end{array}$ & $\begin{array}{c}\text { SP }(0.5) \\
\text { Zero }(0.5)\end{array}$ & $\begin{array}{c}\operatorname{SP}(0.5) \\
\text { Zero }(0.5)\end{array}$ & $\begin{array}{l}\text { MP }(0.1) \\
\text { SP }(0.9)\end{array}$ & $\begin{array}{l}\text { LP }(0.1) \\
\text { MP }(0.9)\end{array}$ \\
\hline
\end{tabular}

$\mathrm{LN}=$ large negative; $\mathrm{SN}=$ small negative; $\mathrm{MN}=$ medium negative; $\mathrm{MP}=$ medium positive $; \mathrm{LP}=$ large positive; $\mathrm{SP}=$ small positive. The number inside the brackets is the degree of assurance this statement provides, and varies from 0 to 1.

errors (SE) in the average distribution was based on the $99.73 \%$ confidence interval for the mean, supported by the Central Limit Theorem (Besterfield, 1990; Mood et al., 1974). As there were three input variables ( $T$; RF; and DS) and one output (RP) it was necessary to arrange the fuzzy rules using two by two sets of base of rules, resulting in six arrays.

Both Tables 1 and 2 were built using knowledge available in literature and the supervision of a beef cattle specialist. The adopted fuzzy function of pertinence was related to level of assurance of each specific statement or relation $X$ to the unity interval $[0,1]$, indicating a nonpertinence statement [0] or a total pertinence of statement [1]. The output function RP was found using the method proposed by Mandani (1974) with both interface of fuzzyfication and defuzzyfication. For defuzzyfication the centroid method was adopted. Some scenarios were simulated to search for the best fit of the model.

\section{Design of an algorithm for predicting the decrease in meat production}

The prediction of decrease in meat production had two steps; first the decrease in production was estimated, and then the cost of production was calculated as a function of the loss in production and reduction of pasture capacity.

Two variables were taken into account for calculating the decrease in production. First, the loss in reproductive index (RI, \%) due to the increase in air temperature was assumed to be within the range of 8.2 to $10 \%$ (semen quality, embryo growing deficiency and abortion rate) as found in current literature (Rosa, 2007; Valle
Table 3 - Assumptions made for estimating the increase in cost of production due to decrease in grazing capacity (quality and quantity).

\begin{tabular}{lcc}
\hline & $\begin{array}{c}\text { Dry } \\
\text { season }\end{array}$ & $\begin{array}{c}\text { Rain } \\
\text { season }\end{array}$ \\
\hline $\begin{array}{l}\text { Units of animal }\left(\mathrm{UA} \mathrm{ha}^{-1}\right) \\
1.25\end{array}$ & 2.00 \\
$\begin{array}{l}\text { Cost of supplement feeding per } \\
\begin{array}{l}\text { animal } \% \text { of the total production } \\
\text { cost) }\end{array}\end{array}$ & 8.70 & 6.90 \\
\hline
\end{tabular}

et al., 2000), and second, the increase in production cost (PC, \%) due to the decrease in pasture capacity that varied from 0 to $100 \%$, was described as a fuzzy model of RP (Eq. 4 and Eq. 5).

$\mathrm{RI}(\%)=f(\delta \mathrm{T}, \mathrm{RP})$

where $\mathrm{PC}=\alpha(\mathrm{RP})^{2}+\beta(\mathrm{RI})+\gamma$

Using these functions three possible settings (optimistic, medium and pessimistic) of thresholds were established considering the upper limit as an increase in the ambient temperature from 1 to $5^{\circ} \mathrm{C}$ (IPCC, 2001a,b; IPCC, 2007), a decrease in the rainfall index down to $60 \%$, with a rainfall index monthly average $(\sim 18.5 \mathrm{~mm})$, and an extension of the dry season up to 180 days; and a lower limit as an increase in the air temperature 1 to $5^{\circ} \mathrm{C}$, an increase in the rainfall index up to $60 \%(\sim 72.5$ $\mathrm{mm}$ ), and a decrease of the dry season down to 50 days. For determining the mitigation needs in order to maintain the same level of meat production due to the decrease of pasture capacity, two actions were considered: first, the decrease in number of animals used per area 
of pasture (unit of animal, UA); and second, the use of grain supplement was introduced, based on the same feeding supply concept adopted during the dry season, when pasture capacity is normally reduced. Table 3 shows the data used to build up the base of rules based on current data and management recommendations (Barcelos, 2007; Lazzarini Neto, 2000; Primavesi, 2003).

A simulation was done by increasing the air temperature $\mathrm{T}$ such as $\mathrm{T}=\mathrm{T}_{0}+\mathrm{T}_{\mathrm{i}}(\mathrm{i}=1: 5)$, where $\mathrm{T}_{0}=$ present temperature and $T_{i}=$ temperature increase, according to IPCC forecast, for reaching the total increase in the cost of production.

\section{Results and Discussion}

The fuzzy model for describing the vulnerability/risk of pasture capacity due to the increase in air temperature was built. From the fuzzy pertinence functions it was possible to generate several scenarios consistent with the results described in the current literature, which reveals a grazing capacity decrease under global warming scenario (Gillard and Moneypenny, 1990; Johnston et al., 1996; McKeon et al., 1990; McKeon et al., 1998; Stafford Smith and Foran, 1998; Topp and Doyle, 1996).

The output pertinence function (Eq. 6) represents the pasture capacity vulnerability or risk (RP, \%), and Table 4 shows the parameters found to represent the membership function.

Table 4 - Membership function parameters for representing the vulnerability/risk of pasture capacity.

\begin{tabular}{lcc}
\hline & $\mu_{i}$ & $\delta_{i}$ \\
\hline LN & -1 & 0.35 \\
MN & -0.66 & 0.35 \\
SN & -0.33 & 0.40 \\
Zero & 0 & 0.53 \\
SP & 0.33 & 0.40 \\
MP & 0.66 & 0.35 \\
LP & 1 & 0.35 \\
\hline
\end{tabular}

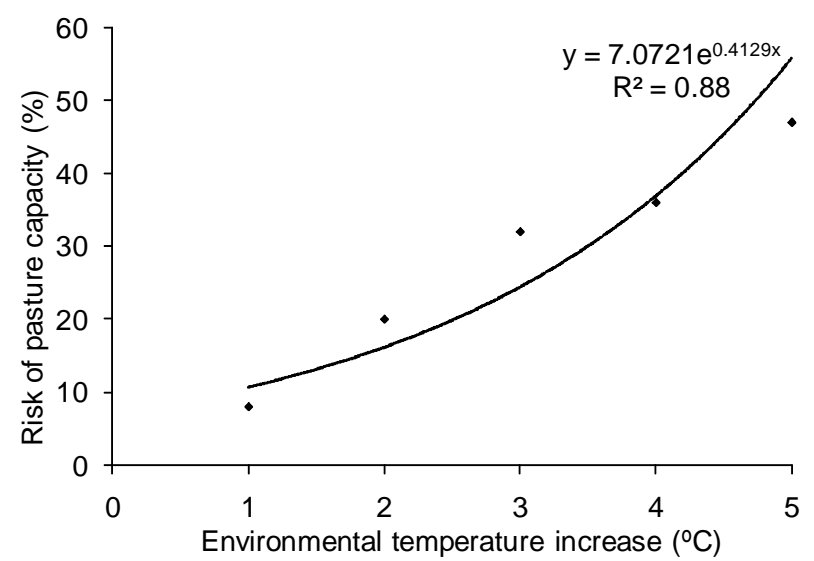

Figure 3 -Scenario for the risk of pasture capacity as environmental temperature increases, using IPCC global warming forecast.
$P R \int_{i}^{n} \equiv \mu_{i} \mid \delta_{i}$

where $\mathrm{i}-0 ; \mathrm{n}=7 ; \mu_{i}=$ average value of the membership function $\mathrm{PR}_{\mathrm{i}}$; and $\delta_{i}=$ standard deviation of the membership function $\mathrm{PR}_{\mathrm{i}}$.

The algorithm resultant of the fuzzy model for each scenario of increase in temperature, as forecasted by IPCC (2001a,b) and IPCC (2007) is presented in Figure 3, and indicates a proportional risk of pasture capacity as the temperature increases. A model was built (Eq. 7) from the fuzzy functions best fit result $\left(\mathrm{R}^{2}=0.88\right)$, for each proposed scenario.

$\mathrm{RP}=7.0721 \mathrm{e}^{0.4129 \mathrm{~T}}$

Models currently available which simulate animal production are dynamic and deterministic, and they can generally be divided into two groups: mechanistic (Freer et al., 1997) and empirical (McCown, 1981; McCown et al., 1981). Both model types are able to account for the variability and uncertainty associated with rainfall by using historical climate data, and empirical models are often more likely to be used as Decision Support Systems. However, greater emphasis on developing a sound theoretical basis generally produces a more robust model that operates better under conditions different from those in which it was developed. In such cases greater confidence would be derived from the use of mechanistic models in simulating the impact of variation or change in climate. In this specific study the level of uncertainty in the changes in that specific geographical area, induced the use of fuzzy models. According to the result, as the air temperature increases, the rainfall index decreases and the extension of the dry season changes at the same time, the grazing land capacity varies considerably.

The models and information reviewed in this study showed that planted (non-native or native species) and native pasture growth, as well as animal production can be limited by a wide range of factors such as soil moisture, air temperature, applied nitrogen and phosphorus; and have a wide range of responses (McKeon et al., 1998). This includes tracing the history of buffering and coping mechanisms employed to reduce vulnerabilities, and a comparison of the local perceptions of the importance of climate variability in beef cattle production.

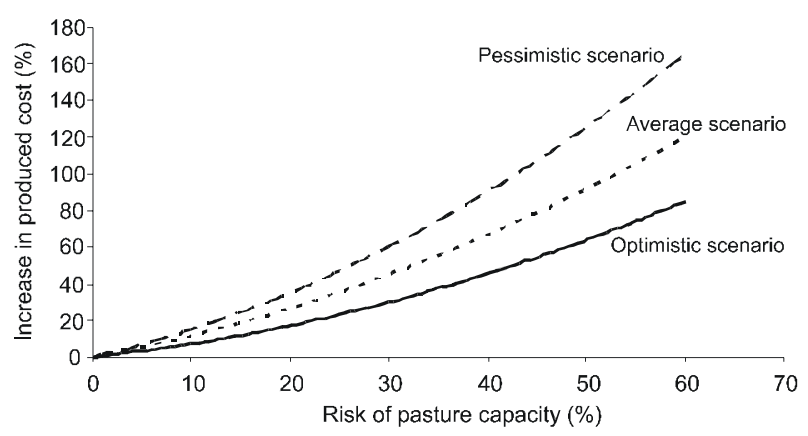

Figure 4 - Scenarios estimation (pessimist, average and optimist) of increase in cost of Brazilian beef cattle production using IPCC global warming forecast. 
The resulting scenario of vulnerability/risk of pasture capacity was used as input in the second fuzzy model, which is the algorithm that estimates the increase in production cost. The results (Figure 4) describe the three final scenarios of increase in cost production of Brazilian beef cattle (\%). As the risk of pasture capacity increases the cost of production also increases (in percentage) as a quadratic function (best fit) for all scenarios: optimist, average and pessimist.

Equation 8 describes the function $\left(R^{2}=0.97\right)$ developed for the optimist scenario, while the function $\left(\mathrm{R}^{2}=\right.$ 0.98 ) found for the average scenario is shown in Equation 9, and the worst scenario is given by the function $\left(\mathrm{R}^{2}=0.97\right)$ described in Equation 10.

$\mathrm{PC}_{\text {opt }}=0.583 \mathrm{RP}$

$\mathrm{PC}_{\text {ave }}=\mathrm{RP}$

$\mathrm{PC}_{\text {pess }}=1.25 \mathrm{RP}$

According to the thresholds set in the simulation, most critical scenarios lead to an impact in the cost of beef production that varies from an increment of $80 \%$ (optimist scenario) to $160 \%$ (pessimist scenario). Similar results were obtained by Hall et al. (1998) using simulation of beef cattle liveweight gain at three locations of Australia. The authors found that $\pm 10 \%$ change in rainfall was magnified to be $\pm 15 \%$ change in animal production (liveweight gain per ha), depending on location and temperature change, and climate change impacts on pasture capacity/risk varied considerably depending on moisture, temperature or soil nutrients. It was also found that this model sensitive study has indicated that a doubling of $\mathrm{CO}_{2}$ may mitigate the potentially negative effects of a combined warmer temperature/reduced rainfall scenario, on the carrying capacity of rangelands. This implies in how the $\mathrm{CO}_{2}$ emissions computing may modify the estimation models for grazing lands.

The majority of beef cattle in Brazil are located on non-native pastures in contrast to countries where beef stocks are fed concentrated grain. The biophysical components of the grazing system are climate, soil and grass which interact to produce the plant dry matter consumed by cattle for maintenance and production. The effect of climate change on agricultural yields may vary by region and by crop. Under certain conditions, the eventual positive physiological effects of $\mathrm{CO}_{2}$ enrichment described in Streck (2005) could be counteracted by temperature increases, leading to shortening of the pasture growth season and changes in precipitation, with consequent reductions in crop yields (IPCC 2001b; IPCC, 2007). In fact, reduced availability of water (either the increase in extent of dry season or the decrease in rainfall index) and warmer temperatures are expected to have negative effects on crops such as wheat, maize, and potentially soybean production in Brazil (Siqueira et al., 1994).

As the herd on pasture is highly dependent on the grass growth, the increase in the dry season may dra- matically affect the production cost, as the cattle will depend more on grain supplement due to the lack in pasture. Nowadays, Brazilian beef average production cost is near US\$ $1.60 \mathrm{~kg}^{-1}$ which is the same as in Uruguay, and it varies between the dry and rainy seasons due to the grazing land capacity. The cost for producing beef in Australia is US $\$ 2.45 \mathrm{~kg}^{-1}$, in Argentina is US\$ $1.50 \mathrm{~kg}^{-1}$, and in the USA is US\$ $3.20 \mathrm{~kg}^{-1}$ (Cultivar, 2007), with little variation between seasons as in those countries there is a mild change in seasonal weather characteristics.

Within the worst scenario Brazilian beef cattle cost of production may reach US $\$ 4.16 \mathrm{~kg}^{-1}$ or under a more favorable scenario, the cost of production may increase to US\$ $2.88 \mathrm{~kg}^{-1}$. In both cases the other producing countries (Uruguay, Argentina and the USA) are under temperate climate and the prognostic impact of global warming is to be less intense than in Brazil. Australian scientists have been studying the impact of climate change in their rangelands in the last ten years, as well as providing mitigation solution for producers, while nothing has been done in Brazil. Under both simulated scenarios, Brazilian beef cattle trend is to decline and lose today's price leading position.

Agriculturalists, in general, are expected to adapt to climate change, and some studies already have been conducted to assess farmers' climate perceptions and adaptation strategies (Brklacich et al., 2000; Chiotti and Johnston, 1995). However, nothing was so far made in Brazil with respect to the estimation of the impact in the pastoral beef cattle production.

Biodiversity of the savannas and native or planted grazing lands have survived prolonged fluctuations in the global thermal variation in the past, but has never experienced the accelerated pace of present global climate change. Little research has been conducted on the impacts of climate change on savanna biodiversity, and this is understandable as the evidence is much stronger for the more immediate impacts of other human activities and land-use practices in the rangelands (Campbell et al., 1997; Stafford and Foran, 1990; Stafford and McKeon, 1998). To fully understand the separate impact of climate change on agricultural production, seek for innovative approaches is needed for tearing apart the signal of climate impact on plant response variables, and the response explained by natural diversity and other human environmental drivers. By identifying synergies with other biodiversity initiatives and adopting historical and present-day climate studies, opportunities for innovative approaches are likely to be forthcoming.

Agricultural production is often affected by extreme climate conditions and the severe consequences have been reported in literature (Pittock, 2003a,b; Rossetti, 2001). Global warming may accelerate photosynthetic activities leading to abnormal plant/pasture development (Bieto and Talon, 1996). The forecasted increase in air temperature is also expected to bring higher incidence of extreme events, such as heat waves, which associated 
to drought may produce higher heat stress on herds reducing even more their productivity (McKeon et al., 1998).

\section{Conclusion}

Global warming under the IPCC scenario may influence the future increase on Brazilian beef cattle cost of production, inducing the loss in its international competitiveness.

There are effective opportunities to manage the grazing lands conservation effectively despite of the climate change. Climate information, together with an understanding of ecosystem dynamics, is increasingly being brought into management decisions and more climate information needs to be incorporated into management tools now. Experiences in other sectors such as agricultural crops show that the most effective way to add information is through cooperative research in which useful on-site applications are developed in collaboration with on-ground producers, building up their capacity for valuable decision-making.

\section{Acknowledgements}

\section{British Council Project - GOF and CEPAGRI - UNICAMP.}

\section{References}

Amendola, M.; Castanho, M.J.; Naas, I.; Souza, A.L. 2004. Análise matemática de condições de conforto térmico para avicultura usando a teoria dos conjuntos Fuzzy. Biomatemática Brazil 14: 87-92.

Barcelos, A.M. 2007. Como obter ganho de peso, mesmo com os pastos secos. Available at: http://www.agrobyte.com.br/ pasto_seco.htm [Accessed Dec. 5, 2007]

Bates, B.C.; Jakeman, A.J.; Charles, S.P.; Sumner, N.R.; Fleming, P.M. 1996. Impact of Climate Change on Australia's Surface Water Resources. Coping with Climate Change, Australia. 1: 248-262.

Bellman, R.E.; Zadeth, L.A. 1970. Decision-making in a fuzzy environment. Management Science 17: 141- 164.

Besterfield, D. 1990. Quality Control. 3 ed. Prentice-Hall, Englewood Cliffs, NJ, USA.

Bieto, J.A.; Talon, M. 1996. Fisiologia y Bioquimica Vegetal. Interamericana, Madrid, Spain.

Brklacich, M.; Bryant, C.; Veenhof, B.; Beauchesne, A. 2000. Agricultural Adaptation to Climatic Change: a Comparative Assessment of Two Types of Farming in Central Canada. Agricultural and Environmental Sustainability in the New Countryside, Halifax, Canada. in Millward, H.; Beesley, K.; Ilbery, B.; Harrington, L. Agricultural and Environmental Sustainability in the New Countryside, Hignell Printing Limited, Winnipeg, pp. 40-51.

Campbell, B.D.; McKeon, G.M.; Gifford, R.M.; Clark, H.; Stafford Smith, D.M.; Newton, P.C.D.; Lutze, J.L. 1996. Impacts of Atmospheric Composition and Climate Change on Temperate and Tropical Pastoral Agriculture. Coping with Climate Change, Australia. pp. 171-189.

Campbell, B.D.; Stafford Smith, D.M.; Mckeon, G.M. 1997. Elevated $\mathrm{CO}_{2}$ and water supply interactions in grasslands: A pastures and rangelands management perspective. Global Change Biology 3: 177-187.
Chiotti, Q.P.; Johnston, T. 1995. Extending the boundaries of climate change research: a discussion on agriculture. Journal of Rural Studies 11: 335-350.

CIG Climate Impact Group . 1996. Climate Change Scenarios for the Australian Region. Commonwealth Scientific and Industrial Research Organisation [CSIRO], Division of Atmospheric Research, Melbourne, Australia. 8p

Clewett, J.F.; Cavaye, J.M.; Partridge, I.J.; McKeon, G.M.; Scanlan, J.C. 1991. Sustaining productive pastures in the tropics 12 . Decision support software as an aid to managing pasture systems. Tropical Grasslands 25:159-64.

Clipperson, S.; Bean, J. 2007. The validation of a pasture growth model for monitoring of seasonal conditions in rangelands. Available at: www.regional.org.au/au/gio/24/ 774clipperton.htm [Accessed Jul. 12, 2007]

Cultivar. Abate antecipado 2007. Available at: http:// www.grupocultivar.com.br/artigo.asp? $\mathrm{id}=212$ [Accessed May $12,2007]$

Diniz, B.P.C. 2006. O grande Cerrado do Brasil: geopolítica e economia. Doctoral Thesis. University of São Paulo, São Paulo, SP, Brazil. (in Portuguese, with Summary in English).

Foran, B.D.; Stafford Smith, D.M. 1991. Risk, biology and drought management strategies for cattle stations in central Australia. Journal of Environmental Management 33: 17-33.

Freer, M.; Moore, A.D.; Donnelly, J.R. 1997. GRAZPLAN: Decision Support Systems for Australian Grazing Enterprises. II. The Animal Biology Model for Feed Intake, Production and Reproduction and the GrazFeed DSS. Agricultural Systems, v.54. USDA, Washington, D.C.

Gillard, P.; Moneypenny, R. 1990. A decision support model to evaluate the effects of drought and stocking rate on beef cattle properties in northern Australia. Agricultural Systems 34: 3752.

Graetz, R.D., Walker, B.H.; Walker, P.A. 1988. The Consequences of Climatic Change for Seventy Per Cent of Australia. Planning for Climate Change. Commonwealth Scientific and Industrial Research Organisation [CSIRO], Melbourne, Australia.

Hall, W.B.; McKeon, G.M.; Carter, J.O.; Day, K.A; Howden, S.M.; Scanlan, J.C.; Johnston, P.W.; Burrows, W.H. 1998. Climate change in Queensland's grazing lands. II. An assessment of the impact on animal production from native pastures. Rangeland Journal 20: 177-205.

Harrington, L.M.B.; Lu, M. 2002. Beef feedlots in southwestern Kansas: local change, perceptions, and the global change context. Global Environmental Change 12: 273-282.

Hendricksen, R.E.; Rickert, K.G.; Ash, A.J.; McKeon, G.M. 1982. Beef production model. Proceedings of the Australian Society of Animal Production Annual Meeting. Australian Society of Animal Production, Melbourne, Australia.

Herne, B.U.S. 1998. Cattle cycle is the key to rising prices. Brigaletter 32: 1-2.

Howden, S.M.; McKeon, G.M.; Walker, L.; Carter, J.O.; Conroy, J.P.; Day, K.A.; Hall, W.B.; Ash, A.J.; Ghannoum, O. 1999. Global change impacts on native pastures in south-east Queensland, Australia. Environmental Modelling and Software 14: 307-316.

Instituto Brasileiro de Geografia e Estatística [IBGE]. 2006. Pesquisa da Agropecuária Municipal. Available at: http:// www.ibge.gov.br/home/estatistica/economia/ppm/2006/ comentarios.pdf [Accessed Nov. 10, 2008]

Intergovernmental Panel on Climate Change [IPCC]. 2001a. Climate Change 2001: Impacts, Adaptation, and Vulnerability. Contribution of Working Group II to the Third Assessment Report of the Intergovernmental Panel on Climate Change. Cambridge University Press, Cambridge, UK.

Intergovernmental Panel on Climate Change [IPCC]. 2001b. Climate Change 2001: The Scientific Basis. Contribution of Working Group I to the Third Assessment Report of the Intergovernmental Panel on Climate Change. Cambridge University Press, Cambridge, UK. 
Intergovernmental Panel on Climate Change [IPCC]. 2008. Climate Change 2007: Synthesis Report. Available at: http:// www.ipcc.ch/pdf/assessment-report/ar4/syr/ar4_syr.pdf [Accessed Nov. 15, 2008]

Johnston, P.W.; Tannock, P.R.; Beale, I.F. 1996. Objective "safe" grazing capacities for southwest Queensland Australia: a model application and evaluation. The Rangeland Journal 18: 259-69.

Lazzarini Neto, S. 2000. Engorda a Pasto. 2ed. Aprenda Fácil, Viçosa, MG, Brazil.

Mandani, E.H. 1974. Application of fuzzy algorithms for control of simple dynamic plant. Procedings of IEEE, 121: 1585-1588.

Marcelino, E.V.; Nunes, L.H.; Kobiyama, M. 2006. Banco de dados de desastres naturais: análise de dados globais e regionais. Caminhos de Geografia 6: 130-149.

Marcelino, E.V. 2007. Desastres Naturais e Geotecnologias: Conceitos Básicos. CRS/INPE, Santa Maria, RS, Brazil.

McCown, R.L. 1981. The climatic potential for beef cattle production in tropical Australia. Part 1. Simulating the annual cycle of liveweight change. Agricultural Systems 6: 303-17.

McCown, R.L.; Gillard, P.; Winks, L.; Williams, W.T. 1981. The climatic potential for beef cattle production in tropical Australia: Part 2 - Liveweight change in relation to agroclimatic variables. Agricultural Systems 7: 1-10.

McKeon, G.M.; Rickert, K.G.; Robbins, G.B.; Scattini, W.J.; Ivory, D.A. 1980. Prediction of animal performance from simple environmental variables. Proceedings of the Fourth Biennial Conference. Simulation Society of Australia, Melbourne, Australia.

McKeon, G.M.; Day, K.A.; Howden, S.M.; Mott, J.J.; Orr, D.M.; Scattini, W.J.; Weston, E.J. 1990. Northern Australian savannas: management for pastoral production. Journal of Biogeography 17: 355-372.

McKeon, G.M.; Charles, S.P.; Bates, B.C.; Hall, W.B. 1998. Methods for Evaluating Climate Change Impacts on Pasture Growth. Final report for the Rural Industries Research and Development Corporation: Evaluation of the Impact of Climate Change on Northern Australian Grazing Industries (DAQ 139A). Rural Industries Research and Development Corporation, Brisbane. Australia. 113-140.

McKeon, G.M.; Hall, W.B; Crimp, S.J.; Howden, S.M.; Stone, R.C.; Jones, D.A. 1998. Climate change in Queensland's grazing lands I. Approaches and climatic trends. Rangeland Journal 20: 151-176.

Mood, A.M.; Graybill, F.A.; Boes, D.C. 1974. Introduction to the Theory of Statistics. 3ed. McGraw-Hill, New York, NY, USA.

Mott, J.J.; Williams, J.; Andrew, M.H.; Gillison. A.N. 1985. Australian savanna ecosystems - Ecology and management of the world's savannas. Australian Academy of Science, Canberra, Australia.

Oliveira, H.L.; Amendola, M.; Nääs, I.A. 2005. Estimativa das condições de conforto térmico para avicultura de postura usando a teoria dos conjuntos Fuzzy. Engenharia Agrícola 25: 300-7.

Pittock, B. 2003a. Climate Change: An Australian Guide to the Science and Potential Impacts. Available at: http:// www.greenhouse.gov.au/science/guide/index.html [Accessed Dec. 5, 2008]

Pittock, B. 2003b. Climate Change and Australia's Natural Resources: A Review. Proceedings of the Conference on Climate Impacts on Australia's Natural Resources: Current and Future Challenges. Standing Committee on Natural Resource Management, Canberra, Australia.

Primavesi, O. 2003. Criação de Bovinos de Corte na Região Sudeste. EMBRAPA Pecuária Sudeste, São Carlos, SP. Available at: http://www.sistemasdeproduao.cnptia.embrapa.br/ FontesHTML/BovinoCorte/BovinoCorteRegiaoSudeste/ aspectosecologicos. htm [Accessed Dec. 10, 2007]

Rangel, T.F.L.V.B.; Bini; L.M.; Diniz-Filho, J.A.F.; Pinto, M.P.; Carvalho, P.; Bastos, R.P. 2007. Human development and biodiversity conservation in Brazilian Cerrado. Applied Geography 27: 14-27.
Rosa, F.T. 2007 Available at: http://www.pioneersementes.com.br/ AtualidadesNoticiasDetalhes.aspx?]d = 2504 [Accessed Dec. 10, 2007]

Rossetti, L.A. 2001. Zoneamento agrícola em aplicações de crédito e securidade rural no Brasil: aspectos atuariais e de política agrícola. Revista Brasileira de Agrometeorologia 9: 386-399.

Ruiz, M.E.; Thiago, L.R.L.S.; Costa, F.P. 1984. Exemplos de sistemas de alimentação na época seca - Alimentação de bovinos na estação seca: princípios e procedimentos. Embrapa Gado de Corte, Campo Grande, MS. Available at: http:// www.cnpgc.embrapa.br/publicacoes/doc/doc20/exemplo.html [Accessed Dec. 15, 2007]

Siqueira, O.J.F.; Farias, J.R.B.; Sans, L.M. 1994. Potential Effects of Global Climate Change for Brazilian Agriculture: applied simulation studies for wheat, maize and soybeans. Implications of Climate Change for International Agriculture, Crop Modeling Study. U.S. Environmental Protection Agency, Washington, D.C., USA.

Sombroek W. 2001. Spatial and temporal patterns of Amazon rainfall: Consequences for the planning of agricultural occupation and the protection of primary forests. Ambio 30: 388-396.

Specht, R.L.; Specht, A. 1995. Global Warming. Predicted Effects on Structure and Species Richness of Mediterranean Ecosystems in Southern Australia: Time scales of biological responses to water constraints. SPB Academic, Amsterdam, Netherlands.

Stafford Smith, D.M.; Foran, B.D. 1990. RANGEPACK: the philosophy underlying the development of a microcomputerbased decision support system for pastoral land management. Journal of Biogeography 17: 541-546.

Stafford Smith, M.; Foran, B. 1992. An approach to assessing the economic risks of different drought management tactics on a South Australian pastoral sheep station. Agricultural Systems 39: 83-105.

Stafford Smith, D.M.; McKeon, G.M. 1998. Assessing the historical frequency of drought events on grazing properties in Australian rangelands. Agricultural Systems 57: 271-299.

Stafford Smith, M., Buxton, R., McKeon, G.; Ash, A. 1998. Seasonal climate forecasting and the management of rangelands: Do production benefits translate into enterprise profits? Applications of seasonal climate forecasting in agricultural and natural ecosystems: The Australian experience. Kluwer Academic Press, Amsterdam, Netherlands.

Sreck, N.A. 2005. Climate change and agroecosystems: The effect of elevated atmospheric $\mathrm{CO}_{2}$ and temperature on crop growth, development, and yield. Ciência Rural 35: 730-740.

Streck, N.A.; Alberto, C.M. 2006. Numerical study of the impact of climate change on the yield of wheat, soybean and maize. Pesquisa Agropecuária Brasileira 41: 1351-1359.

Topp, C.F.E.; Doyle, C.J. 1996. Simulating the impact of global warming on milk and forage production in Scotland. 2. The effects on milk yields and grazing management of dairy herds. Agricultural Systems 52: 243-270.

Valle, E.R.; Andreotti, A.R.; Thiago, R.L.S. 2000. Técniques of Beef Cattle Reproduction management. Embrapa Gado de Leite, Campo Grande, MS, Brazil.

White, B.J. 1972. Supply projections for the Australian beef industry. Review of Marketing and Agricultural Economics 40: 1-12.

White, B.J. 1978. A Simulation Based Evaluation of Queensland's Northern Sheep Industry. Monograph Series 10. Department of Geography, James Cook University, Townsville, Australia.

Wicksteed, L.T. 1980. A model of beef production systems: central sub-coastal speargrass zone of Queensland. Proceedings of the Australian Society of Animal Production 13: 361-364.

Zimmer, A.H.; Euclides Filho, K. 1997. As Pastagens e a Pecuária de Corte Brasileira. Anais do Simpósio Internacional sobre Produção Animal em Pastejo. Universidade Federal de Viçosa [UFV], Viçosa, MG, Brazil.

Received April 29, 2008

Accepted July 27, 2009 